\title{
Erythropoietin Potentiates the Anti-Proliferative Effect of Tamoxifen in Ovarian Adenocarcinoma A2780 Cells
}

\author{
Patrícia Kimáková, ${ }^{1}$ Erika Szentpéteriová, ${ }^{1}$ Barbora Fecková, ${ }^{1}$ \\ Nataša Debeljak ${ }^{2}$ and Peter Solár ${ }^{1,3, *}$ \\ ${ }^{1}$ Department of Cell Biology, Institute of Biology and Ecology, Faculty of Science, Pavol Jozef Šafárik University in Košice, \\ SK-04154 Košice, Slovak Republic \\ ${ }^{2}$ Institute of Biochemistry, Faculty of Medicine, University of Ljubljana, SI-1000 Ljubljana, Slovenia \\ ${ }^{3}$ Department of Medical Biology, Faculty of Medicine, Pavol Jozef Šafárik University in Košice, SK-04154 Košice, \\ Slovak Republic \\ *Corresponding author: E-mail: peter.solar@upjs.sk
}

Received: 07-05-2018

\begin{abstract}
We have recently shown that erythropoietin receptor (EPOR) protects cancer cells from tamoxifen (TAM)-induced cell death in the absence of erythropoietin (EPO). In this study, we analyzed the effect of EPOR silencing and EPO treatment on the response to TAM in human ovarian adenocarcinoma cells A2780. We demonstrated that the EPOR siRNA silencing decreases cell proliferation and sensitizes and/or potentiates the anti-proliferative effect of TAM on A2780 cells. Similarly, the combined effect of EPO and TAM treatment significantly reduced cell proliferation compared to TAM alone. Our in vitro results indicated the need for further investigation of EPO effects on a similar in vivo model.
\end{abstract}

Keywords: Erythropoietin receptor; erythropoietin; tamoxifen; A2780; cancer cell line

\section{Introduction}

Erythropoietin (EPO) is a glycoprotein, the biological effects of which are mediated through the binding to the EPO receptor (EPOR). EPOR is expressed not only in erythroid cells, but also in many non-hematopoietic cells including vascular endothelial and cancer cells. ${ }^{1}$ Several scientists have proved the presence of EPOR expression in ovarian cancer cells, ${ }^{2-4}$ with contrasting results regarding its localization and functionality. Solár et al. ${ }^{5}$ uncovered only a poor EPOR signal in A2780 cells, where EPOR protein was found in the cytoplasm as an intracellular membrane-associated rather than a soluble protein. Silencing of EPOR expression resulted in reduced A2780 proliferation as well as a reduction of EPO-induced ERK1/2 phosphorylation. ${ }^{5}$ Indeed, the formation of EPO-EPOR complex resulted in the activation of many proteins, ${ }^{6}$ such as Janus kinase (JAK), Signal transducer and activator of transcription (STAT), ${ }^{7}$ as well as other signal pathways involved in cell proliferation, survival and/or gene expression control. ${ }^{8}$ The presence of EPOR in tumor cells question its possible negative effects on both tumor cell proliferation and the in- hibition of apoptosis. In fact, these effects might be induced by recombinant human EPO or its analogs (e.g., erythropoiesis-stimulating agents, ESA) in cancer patients who suffer from chemotherapy-induced anemia. ${ }^{9}$

Tamoxifen (TAM) is classified as a selective estrogen receptor modulator (SERM) ${ }^{10}$ that exerts its anti-proliferative action by binding to the estrogen receptor (ER) and blocking the mitogenic effect of estradiol. ${ }^{11}$ Although it has been used extensively in the treatment of ER positive breast cancer, ${ }^{12}$ its effectiveness was also shown in the treatment of estradiol-independent neoplasia, such as ER-negative breast cancer ${ }^{13}$ and ovarian cancer. ${ }^{14}$ However, the mechanism underlying the anti-proliferative action of TAM in tumor cells has not been completely clarified, as the induction of apoptosis could also mediate its cytotoxic effect. ${ }^{15}$ Moreover, many studies have demonstrated that TAM acts in both cytostatic (arrest of G0/G1 phase) and cytotoxic (inducing apoptosis) manners. ${ }^{16,17}$ It was shown that $1 \mu \mathrm{M}$ of TAM induced cell cycle arrest in G1 phase, ${ }^{18}$ whereas concentration between 5 and $50 \mu \mathrm{M}$ TAM induced apoptosis. ${ }^{17}$ This dual effect suggests that TAM can be used as a checkpoint between the cell cycle arrest and apoptosis. 
Based on our previous results which showed that EPOR protects cancer cells against TAM-induced cell death even in the absence of EPO. ${ }^{19}$ In this study, we aimed to analyze the effect of EPOR silencing as well as the effect of EPO treatment on the anti-proliferative potential of TAM therapy in human ovarian adenocarcinoma cells A2780.

\section{Experimental}

\section{1. Cell lines and Cell Culture}

Human ovarian adenocarcinoma cell line A2780 was obtained from the American Tissue Culture Collection and grown in RPMI-1640 medium (Life Technologies, Carlsbad, CA, USA) supplemented with $10 \%$ fetal calf serum (FCS) (Life Technologies) and the antibiotic/antimycotic solution ( $100 \mathrm{U} / \mathrm{ml}$ penicillin, $100 \mu \mathrm{g} / \mathrm{ml}$ streptomycin, and $25 \mu \mathrm{g} / \mathrm{ml}$ amphotericin B, Life Technologies). The cells were maintained in the incubator under standard tissue culture conditions at $37^{\circ} \mathrm{C}, 95 \%$ air $/ 5 \% \mathrm{CO}_{2}$.

\section{2. IncuCyte ZOOM System}

We performed the experiments using an IncuCyte ZOOM system (Essen BioScience, Ann Arbor, MI, USA), which consists of a microscope with a $20 \times$ objective (Nikon) placed inside the incubator and a networked external controller hard drive that gathers and processes image data. The A2780 cells were seeded in the antibiotic free medium in tetraplicates in 96-well plates at 5000 cells/ well (as $100 \mu \mathrm{l}$ cell suspension/well) and placed in the IncuCyte ZOOM system. After the initial $24 \mathrm{~h}$ of incubation, medium was removed, the siRNA prepared by DharmaFECT general transfection protocol (http://www.molecularinfo.com/MTM/K/K1/K1-1/K1-1-16.pdf) at the concentration of $2 \mu \mathrm{M}$ (in the total volume of $100 \mu \mathrm{l}$ antibiotic free medium) was added and followed by the incubation of cells for $48 \mathrm{~h}$. After this period, cells were treated with $12.5 \mu \mathrm{M}$ TAM and/or EPO (10 IU/ml and $100 \mathrm{IU} /$ $\mathrm{ml})$ in the antibiotic free medium $(200 \mu \mathrm{l}$ medium/well $)$ and incubated for $72 \mathrm{~h}$. The IncuCyte ZOOM system automatically monitored the cell confluence in each well every $2 \mathrm{~h}$ up to $72 \mathrm{~h}$ of TAM treatment. The experiment was performed three times. The data from three independent experiments are presented as the mean normalized Cell Index curves $\pm \mathrm{SD}$.

\section{3. Western Blotting}

The A2780 cells were seeded in antibiotic free medium $(3 \mathrm{ml} /$ well $)$ in 6 -well plates at $4.5 \times 10^{5}$ cells/well. After $24 \mathrm{~h}$, siRNA prepared by DharmaFECT general transfection protocol was added and cells were incubated for additional 96 hours at $37^{\circ} \mathrm{C}$ in $5 \% \mathrm{CO}_{2}$. The medium was replaced with new antibiotic free medium and cells were incubated with TAM, EPO, and TAM+EPO for $15 \mathrm{~min}$, fol- lowed by cell lysis and protein isolation. The cells were lysed for $10 \mathrm{~min}$ in lysis buffer on ice and the soluble proteins were recovered in the supernatant followed by centrifugation at $12,000 \times \mathrm{g}$ for $10 \mathrm{~min}$. The protein samples were separated on $12 \%$ SDS-PAGE gels, electroblotted onto Immobilon-P transfer membrane (Millipore Co., Billerica, MA, USA), and incubated overnight with primary antibodies: anti-p44/42 MAP kinase (\#9102, 1:1000, Cell Signaling Technology, Danvers, MA, USA), anti-phospho-p44/42 MAP kinase (\#9102, 1:1000, Cell Signaling Technology), anti-EPOR A82 (1:1250; Amgen, Inc., CA, USA, donated from Amgen), and anti- $\beta$-actin (clone AC$74,1: 10000$, Sigma). The membranes were then incubated with secondary horseradish peroxidase-conjugated antibodies, Goat anti-Rabbit IgG F(AB') 2 (1:10000, PI-31461, Thermo Fisher Scientific, Loughborough, UK) and Goat anti-Mouse IgG F(AB') 2 (1:10000, PI-31436, Thermo Fisher Scientific), for $1 \mathrm{~h}$ and subsequently visualized with ECL Western blotting substrate (PI-32106, Pierce) using Kodak Biomax films (\#1788207, Sigma-Aldrich). Protein bands were quantified using ELLIPSE software version 2.0.7.1 (ViDiTo, SR).

\section{Results and Discussion}

Both downregulation of EPOR as well as TAM therapy reduced cell proliferation of A2780 cells compared to controls. Moreover, their mutual combination reduced cell proliferation in greater extent compared to TAM treatment alone (Fig.1A). On the other hand, while siRNA against EPOR decreased the phosphorylation of ERK1/2 proteins, conversely TAM increased the phosphorylation. Interestingly, the combination of siRNA against EPOR and TAM therapy reduced the phosphorylation of ERK1/2 proteins compared to TAM treatment alone (Fig.1B).

We therein confirmed our previous results, indicating that EPOR plays a significant role in the proliferation of A2780 cells. Many other studies have also indicated that EPO/EPOR plays a role in tumor progression ${ }^{20}$ mainly through the stimulation of cell proliferation and/or inhibition of apoptosis. On the other hand, some studies have claimed that despite of EPOR presence in cancer cells, its biological activity is weak ${ }^{4}$ and does not lead to increased tumor cell proliferation after EPO stimulation. ${ }^{21}$

Our results correlate with in vivo study of the Paragh et al. ${ }^{4}$ in which inhibition of EPOR expression led to abrogated A2780 tumor xenograft growth with reduced EPOR signaling. Our current and previous EPOR silencing study, ${ }^{5}$ together with Paragh et al., ${ }^{4}$ yielded identical results, showing reduced cell proliferation of A2780 cells. On the other hand, Swift et $\mathrm{al}^{2}$ found no effect of EPOR knockdown on the viability of A2780. Application of different cell lines and different culturing (inactivated or regular serum) and/or experimental conditions could also account for inconsistent EPOR results. 


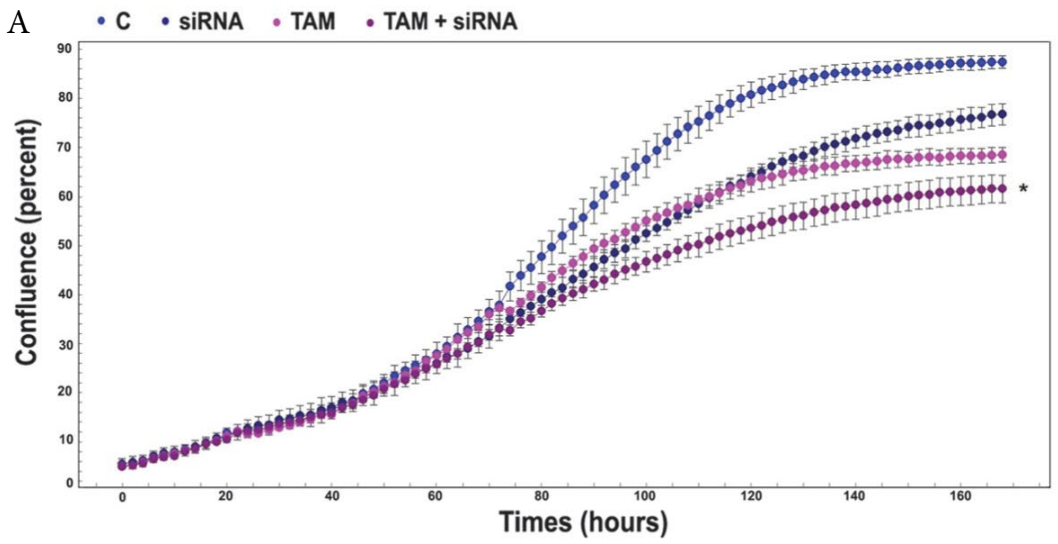

B

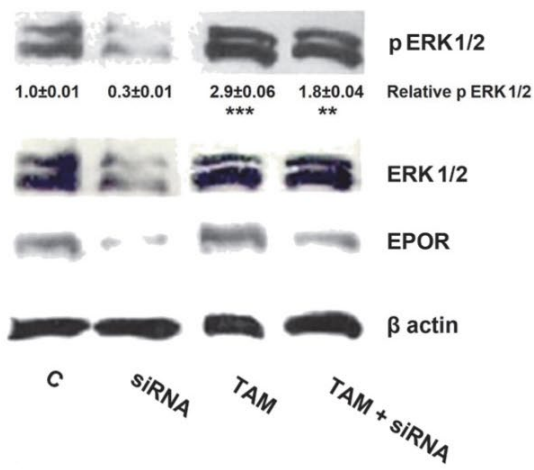

Figure 1. The effect of siRNA against EPOR and/or TAM exposure on the proliferation and signaling of A2780 cells. Four groups of A2780 cells were set: control cells (C), cells incubated with siRNA against EPOR (siRNA), cells incubated with tamoxifen (TAM, $12.5 \mu \mathrm{M}$ ), and cells incubated with EPOR siRNA in combination with TAM (TAM+siRNA). A. Cell proliferation data were normalized through the cell index curves \pm standard deviations of three independent experiments. Asterisk $\left.{ }^{*}\right)$ designates statistically significant difference in cell proliferation between TAM+siRNA versus TAM at $\mathrm{p}<0.05$. B. Western blott analysis of EPOR, ERK1/2, and phosphorylated ERK1/2 (p ERK1/2). Ratios \pm standard deviations from quantitative densitometric analysis of $\mathrm{p}$ ERK1/2 were normalized to ERK1/2. Equal loading was confirmed by detection of $\beta$-actin. Ratio of $C$ was arbitrarily set to $1 .{ }^{* *} \mathrm{p}<0.01 ;{ }^{* *} \mathrm{p}<0.001$ versus $\mathrm{C}$ (three independent experiments; one-way ANOVA tests).

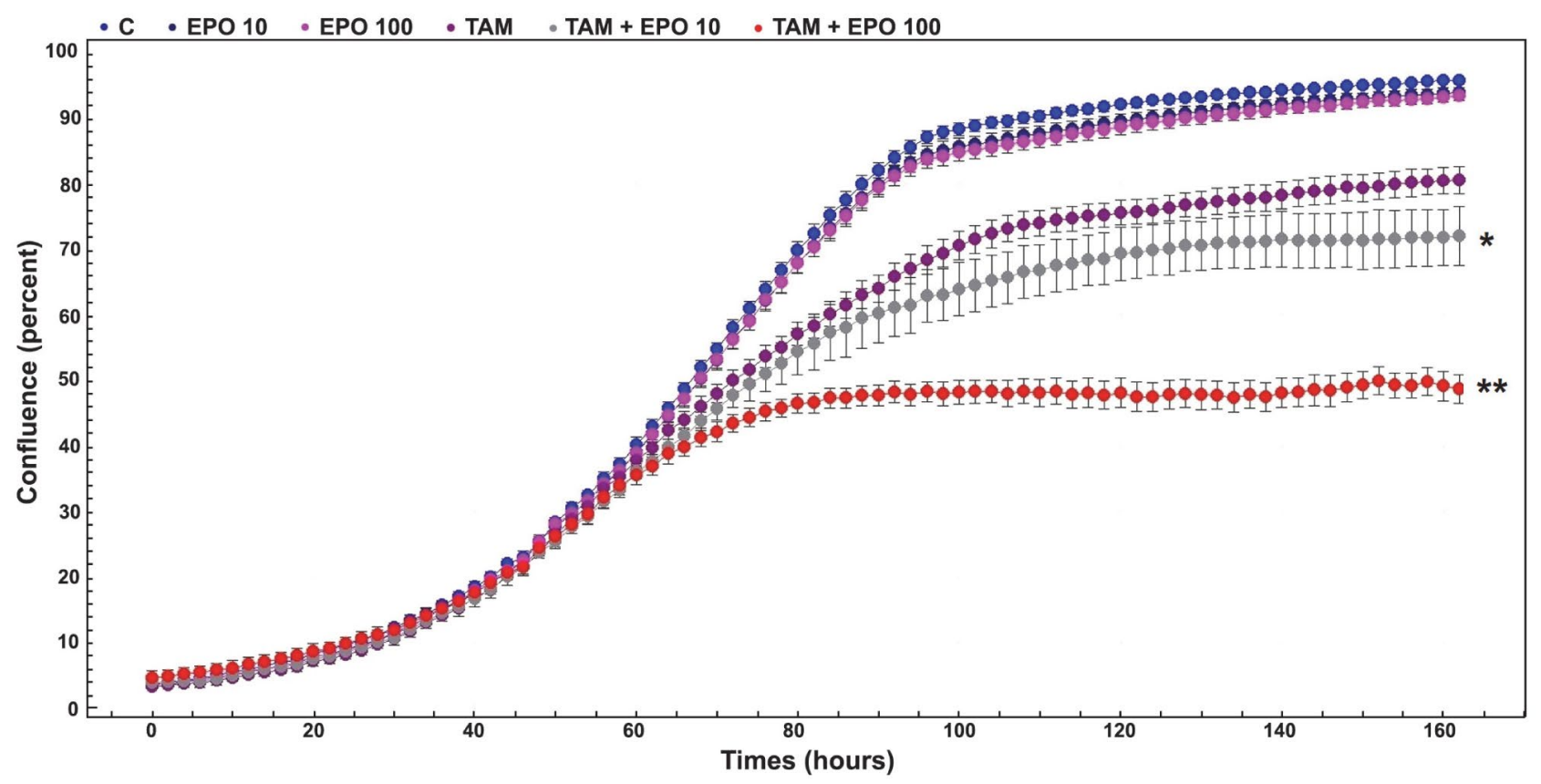

Figure 2. The effect of EPO and/or TAM on the proliferation of A2780 cells. The A2780 cells were incubated with erythropoietin (EPO) at concentrations of $10 \mathrm{IU} / \mathrm{ml}(\mathrm{EPO} 10)$ or $100 \mathrm{IU} / \mathrm{ml}$ (EPO 100), with tamoxifen (TAM, $12.5 \mu \mathrm{M})$, or with their combinations TAM+EPO 10 or TAM+EPO 100. Data are normalized through the cell index curves \pm standard deviations of three independent experiments. Asterisk $\left({ }^{*}\right)$ designates statistically significant difference in cell proliferation between TAM+EPO 10 versus TAM at $\mathrm{p}<0.05$ and two asterix $\left({ }^{*}\right)$ indicates significant difference in cell proliferation between TAM+EPO100 versus TAM at $\mathrm{p}<0.01$.

The incubation of A2780 cells with pharmacological concentrations of EPO $(10 \mathrm{IU} / \mathrm{ml}$ or $100 \mathrm{IU} / \mathrm{mL})$ resulted in proliferation comparable to that of the control; however, EPO did potentiate the anti-proliferative effect on TAM exposed cells (Fig. 2).

Our study showed for the first time that EPOR siRNA silencing sensitizes and/or potentiates the anti-proliferative effect of TAM on A2780 cells (Fig. 1A). This finding is consistent with our recent study in which EPOR overexpression showed a protective effect on rat mammary adenocarcinoma cells RAMA 37-28 against TAM without the addition of EPO. In this regard, although the proliferation potential of parental RAMA 37 (low/no EPOR expression) was higher under the control conditions, the treatment with TAM affected RAMA 37 cells more and resulted in a greater inhibition of proliferation and more significant cell 
death than in EPOR overexpressed RAMA 37-28 cells. $^{19}$ Moreover, the same study demonstrated early ( 5 min after TAM addition) response of RAMA 37 and RAMA 37-28 to TAM treatment with the activation of RAS/MAPK signaling pathway and ERK1/2 phosphorylation. In this regard, TAM-activated phosphorylation of ERK1/2 was slightly faster and more powerful in parental RAMA 37 than in RAMA 37-28 cells. ${ }^{19}$ Similarly, ERK1/2 signalization together with other cascades were also involved in ER-positive and -negative as well as cisplatin-resistant and -sensitive ovarian cancer cells' response to TAM therapy, which led to the cell-cycle arrest in the G1 phase. ${ }^{20}$ On the other hand, TAM activated ERK2 and JNK1 in HeLa cells ${ }^{21}$ as well as in ER-negative MDA-MB-231 breast cancer cells in which the expression of dominant-negative JNK prevented TAM-induced apoptosis. ${ }^{22}$ Similarly, the combination of TAM with inhibitors of PKCa and ERK could promote TAM-induced apoptosis in breast cancer cells. ${ }^{23}$ Interestingly, EPOR down-regulation potentiated the anti-proliferative effect of TAM therapy and reduced TAM activated ERK1/2 phosphorylation in A2780 cells (Fig. 1B). Based on mentioned above results it seems that ERK1/2 proteins may have a dual function in TAM induced tumor cells, as both anti-proliferative as well as cell-protective effects are observed. Indeed, further studies are needed to explain when a particular effect of Erk1/2 is manifested.

Furthermore, our current study revealed also that pharmacological concentrations of EPO $10 \mathrm{IU} / \mathrm{ml}$ and 100 $\mathrm{IU} / \mathrm{ml}$ increase the effect of TAM, so the combination of EPO and TAM significantly reduces the proliferation of ER-negative A2780 cells compared to TAM therapy alone (Fig. 2). Rasedee et al., ${ }^{24}$ demonstrated the synergistic effect of EPO and TAM combination which was capable of reducing the clonogenicity of the cancerous cells and cell viability significantly more than TAM alone. Moreover, the combination of EPO and TAM resulted in a $90 \%$ tumor regression in mammary tumor-induced Sprague Dawley rats, which was $20 \%$ more than that obtained with TAM alone. ${ }^{25}$ Recently, EPO-conjugated TAM-loaded lipid nanoparticles enhanced the in vitro cytotoxicity of TAM to MCF-7 cells and showed that EPOR expressed on cancer cells is a potential receptor for drug-targeted therapy. ${ }^{26} \mathrm{Al}$ though EPOR has been detected with specific A82 antibody in A2780 cells (Fig. 1B), neither the effect of $10 \mathrm{IU} /$ $\mathrm{ml}$ nor the effect of $100 \mathrm{IU} / \mathrm{ml}$ of EPO on the proliferation of these cells was observed. On the contrary, $100 \mathrm{IU} / \mathrm{ml}$ of EPO suppressed cell proliferation of A2780 cells by $30 \%$ more than TAM alone (Fig. 2).

What underlies such potentiating effect of EPO on TAM therapy? In theory, it might be ERK1/2 and/or PKC signalization induced by both EPO and TAM exposure ${ }^{5,23}$ but also EPO activated JAK2/STAT5 or PI3K. ${ }^{9}$ Future study should identify specific signal pathway(s) which is (are) responsible for the potentiating effect of EPO on TAM therapy of A2780 cells.

\section{Conclusions}

Finally, siRNA against EPOR confirmed our previous results, which supported the role of EPOR protein in the proliferation of human ovarian adenocarcinoma cells A2780. In addition, we outlined the potentiating effect of EPO on TAM therapy in A2780 cells in vitro, which could benefit future investigations on the EPO effects in similar in vivo model and to indicate a possible relationship to the clinic.

\section{Conflict of Interest}

There is no conflict of interest

\section{Acknowledgements}

The present study was supported by the Scientific Grant Agency of the Ministry of Education, Science, Research, and Sport of the Slovak Republic (Bratislava, Slovak Republic, grant no. VEGA 1/0394/15).

\section{References}

1. M. E. Hardee, M. O. Arcasoy, K. L. Blackwell, J. P. Kirkpatrick and M. W. Dewhirst, Clin Cancer Res 2006, 12, 332-9.

DOI:10.1158/1078-0432.CCR-05-1771

2. S. Swift, A. R. Ellison, P. Kassner, I. McCaffery, J. Rossi, A. M. Sinclair, C. G. Begley and S. Elliott, Blood 2010, 115, 4254-63. DOI:10.1182/blood-2009-10-248674

3. J. Y. Jeong, L. Feldman, P. Solar, J. Szenajch and A. J. Sytkowski, Int J Cancer 2008, 122, 274-80.

DOI:10.1002/ijc.23068

4. G. Paragh, S. M. Kumar, Z. Rakosy, S. C. Choi, X. Xu and G. Acs, Am J Pathol 2009, 174, 1504-14.

DOI:10.2353/ajpath.2009.080592

5. P. Solar, G. Hrckova, L. Varinska, Z. Solarova, J. Kriska, I. Uhrinova, M. Kello, J. Mojzis, P. Fedorocko and A. J. Sytkowski, Oncol Rep 2012, 28, 141-6.

6. S. S. Watowich, D. J. Hilton and H. F. Lodish, Mol Cell Biol 1994, 14, 3535-49. DOI:10.1128/MCB.14.6.3535

7. V. Pelekanou, M. Kampa, M. Kafousi, K. Dambaki, K. Darivianaki, T. Vrekoussis, E. Sanidas, D. D. Tsiftsis, E. N. Stathopoulos and E. Castanas, Cancer Epidemiol Biomarkers Prev 2007, 16, 2016-23.

DOI:10.1158/1055-9965.EPI-06-1023

8. J. E. Darnell, Jr., I. M. Kerr and G. R. Stark, Science 1994, 264, 1415-21. DOI:10.1126/science.8197455

9. N. Debeljak, P. Solar and A. J. Sytkowski, Front Immunol 2014, 5, 563. DOI:10.3389/fimmu.2014.00563

10. B. Fisher, J. P. Costantino, C. K. Redmond, E. R. Fisher, D. L. Wickerham and W. M. Cronin, J Natl Cancer Inst 1994, 86, 527-37. DOI:10.1093/jnci/86.7.527 
11. V. C. Jordan, Breast Cancer Res Treat 1990, 15, 125-36. DOI:10.1007/BF01806350

12. R. R. Love, J Clin Oncol 1989, 7, 803-15. DOI:10.1200/JCO.1989.7.6.803

13. I. A. Jaiyesimi, A. U. Buzdar, D. A. Decker and G. N. Hortobagyi, J Clin Oncol 1995, 13, 513-29.

DOI:10.1200/JCO.1995.13.2.513

14. M. Markman, K. A. Iseminger, K. D. Hatch, W. T. Creasman, W. Barnes and B. Dubeshter, Gynecol Oncol 1996, 62, 4-6. DOI:10.1006/gyno.1996.0181

15. E. P. Gelmann, J Natl Cancer Inst 1996, 88, 224-6. DOI:10.1093/jnci/88.5.224

16. C. K. Osborne, D. H. Boldt, G. M. Clark and J. M. Trent, Cancer Res 1983, 43, 3583-5.

17. R. R. Perry, Y. Kang and B. Greaves, Ann Surg Oncol 1995, 2, 238-45. DOI:10.1007/BF02307030

18. A. M. Otto, R. Paddenberg, S. Schubert and H. G. Mannherz, J Cancer Res Clin Oncol 1996, 122, 603-12. DOI:10.1007/BF01221192

19. L. Ilkovicova, N. Trost, E. Szentpeteriova, P. Solar, R. Komel and N. Debeljak, Int J Oncol 2017, 51, 737-746.

DOI:10.3892/ijo.2017.4061
20. S. Mabuchi, M. Ohmichi, A. Kimura, Y. Ikebuchi, K. Hisamoto, E. Arimoto-Ishida, Y. Nishio, K. Takahashi, K. Tasaka and Y. Murata, Endocrinology 2004, 145, 1302-13. DOI:10.1210/en.2003-0709

21. J. L. Duh, R. Yu, J. J. Jiao, G. A. Matwyshyn, W. Li, T. H. Tan and A. N. Kong, Pharm Res 1997, 14, 186-9. DOI:10.1023/A:1012048626963

22. S. Mandlekar, V. Hebbar, K. Christov and A. N. Kong, Cancer Res 2000, 60, 6601-6.

23. Z. Li, N. Wang, J. Fang, J. Huang, F. Tian, Ch. Li, and F. Xie, Oncol Rep 2012, 27, 1879-86. DOI:10.3892/or.2012.1635

24. A. Rasedee, R. Rozita, B. M. A. Noorjahan and G. Y. Teo, Paper presented at: International Exposition of Research and Innovations of Instituitions of Higher Learning (PECIPTA). Organized by Ministry of Higher Education and University of Science Malaysia; August 10-12, 2007; Kuala Lumpur.

25. A. K. Sairah, A. Rasedee, O. Sheikh, R. Rozita and N. Al-Haj, Am J Pharmacol Toxicol 2009, 4, 12-6.

DOI:10.3844/ajptsp.2009.12.16

26. Ch. Y. Beh, Ch. W. How, J. B. Foo, J, N, Foong, G. T. Selvarajah and A. Rasedee, Drug Des Devel Ther 2017, 11, 771-82. DOI:10.2147/DDDT.S123939

\section{Povzetek}

Pred kratkim smo pokazali, da receptor za eritropoetin (EPOR), tudi v odsotnosti eritropoetina (EPO), ščiti rakave celice pred s tamoksifenom (TAM) povzročeno celično smrtjo. V trenutnem članku smo analizirali odzivnost človeških ovarijskih adenokarcinomskih celic A2780 na TAM ob utišanju EPOR in izpostavitvi EPO. Pokazali smo, da utišanje EPOR s siRNA zmanjša celično proliferacijo in senzibilizira in / ali poveča antiproliferativni učinek TAM na celice A2780. Sočasen učinek zdravljenja z EPO in TAM bistveno zmanjša proliferacijo celic v primerjavi s samim TAM. Naši rezultati in vitro nakazujejo potrebo po nadaljnji raziskavi učinkov EPO na modelu in vivo ter predstavljajo izziv za prihodnje klinične raziskave. 